\title{
PENDAMPINGAN PEMBELAJARAN BACA TULIS AL QURAN PADA SISWA SD NEGERI 2 KUWASEN JEPARA
}

\author{
1) Mahalli, ,2 Khalimatus Sadiyah, ${ }^{3)}$ Sa'adatul Kholili \\ ${ }^{1,2,3}$ Program Studi PAI, FTIK, UNISNU Jepara \\ 1,2,3)J1 Tamansiswa, Tahunan Jepara, Indonesia \\ E-Mail :favimillati@gmail.com, elkhasya.jpr@gmail.com,saadatulkholili01@gmail.com
}

\begin{abstract}
ABSTRAK.
Kemampuan baca tulis al Quran adalah ketrampilan dasar guna menunjang prestasi belajar mata pelajaran Pendidikan Agama Islam (PAI) pada siswa SD Negeri 2 Kuwasen. Ada data awal yang menunjukkan bahwa siswa kelas V.SD N 2 Kuwasen memiliki kemampuan baca tulis al Quran yang masih rendah, sementara alokasi waktu yang tersedia dalam struktur kurikulum SD dan guru PAI belum memadahi untuk menangani masalah tersebut, sehingga memerlukan waktu khusus di luar jam intra kurikuler. Kegiatan pengabdian ini bertujuan untuk melakukan pendampingan pembelajaran BTQ siswa kelas V SD Negeri 2 Kuwasen yang diharapkan akan meningkatkan kemampuan baca tulis al Quran. Pendampingan dilaksanakan dengan pembelajaran tata muka di kelas di luar jam intra kurikuler sebanyak 36 kali, dengan menggunakan metode ceramah, demonstrasi/simulasi, dan praktek. Evaluasi hasil pendampingan dilaksanakan dengan tehnik tulis dan lisan. Hasil pengabdian ini menunjukkan bahwa pendampingan dalam pembelajaran BTQ, memiliki dampak positif dalam meningkatkan kemampuan baca dan tulis al Quran siswa kelas V SDN 2 Kuwasen. Hal ini bisa dilihat dengan membandingkan rata-rata nilai pre-test sebesar 65,4 dengan rata-rata nilai post-test sebesar 78,1.
\end{abstract}

Kata Kunci; pendampingan, BTQ, SD Negeri 2 Kuwasen

\section{ABSTRACT.}

Students' ability to read and write the Holy Quran is a basic skill that greatly supports the mastery of Islamic Religious Education (PAI) subject matter. Initial data shows that students in grade VSD N 2 Kuwasen have low ability to read and write the Holy Quran, while the time allocation available in the elementary school curriculum structure and Islamic Education teachers are not sufficient to deal with this problem, so it requires special time outside intracurricular hours. This community service aims to assist the fifth grade students of SD Negeri 2 Kuwasen in learning to read and write the Holy Quran by mentoring them in learning activities outside the intra curricular time. Mentoring is carried out with face-to-face learning in the class room outside of intra-curricular hours as many as 36 times, using lecture, demonstration/simulation, and practice methods. Evaluation of mentoring results is carried out using written and oral test techniques. The results of this activity indicate that mentoring in BTQ learning has a positive impact in improving the reading and writing skills of the fifth grade students of SDN 2 Kuwasen. This can be seen by comparing the average pre-test scores of 65.4 with the average post-test scores of 78.1.

Keywords; assist, BTQ, SD Negeri 2 Kuwasen

\section{PENDAHULUAN \\ Latar Belakang}

SD Negeri 2 Kuwasen adalah sekolah dasar yang berlokasi di desa Kuwasen RT 08 RW 02 kecamatan Jepara Kota, kabupaten Jepara. SD ini berada di lokasi perkotaan yang mana sebagian besar masyarakatnya bekerja di pabrik/perusahaan, dan di lokasi ini tidak banyak lembaga pendidikan al Quran yang memungkinkan siswa SD untuk menambah wawasan dan keterampilan dalam baca dan tulis al Quran di luar waktu belajar di SD. Disamping itu juga faktor motivasi siswa dan perhatian orang tua mereka yang masih rendah untuk mendorong anaknya mengikuti pembelajaran di lembaga pendidikan al Quran, sehingga pembinaan kemampuan baca dan tulis al Quran hanya diperoleh dari pembelajaran PAI di SD yang sangat terbatas waktunya [1]. Data awal hasil pre-test kemampuan baca dan tulis al Quran siswa kelas V SD memperoleh rata-rata 64,9 untuk baca dan 65,6 untuk tulis. Berangkat dari permasalahan di atas penulis terpanggil untuk melakukan pendampingan pembelajaran BTQ bagi siswa kelas V SD sebagai bentuk kegiatan 
pengabdian kepada masyarakat, dengan tujuan agar kemampuan BTQ mereka dapat meningkat dengan baik. Secara etimologis pembelajaran baca tulis al Quran adalah melafalkan dan menulis ayat-ayat al Quran dengan mengetahui kaidah-kaidah yang telah ditetapkan seperti makharijul huruf, panjang pendek, tajwid, dan kaidah penulisan sehingga tidak terjadi perubahan makna pada ayat al Quran. Kecakapan dalam membaca dan menulis al Quran merupakan keterampilan dasar yang harus dimiliki oleh setiap umat Islam dimulai dari masa anak-anak, karena masa anakanak adalah masa pembentukan karakter atau watak yang baik, sehingga mereka akan terdidik sejak usia anak-anak tentang kecintaan nya pada al Qura, sekaligus pemantapan iman secara sempurna dan akidah yang mendala. Mengingat al Quran sebagai kitab suci umat Islam sekaligus sebagai pedoman hidup menuju jalan kebenaran [7]. Dalam surat al 'Alaq secara eksplisit Allah memerintahkan belajar membaca dan menulis al Quran [4].

Tinjauan hasil penelitian terdahulu terkait dengan topik penelitian ini menunjukkan bahwa program pendampingan dalam kegiatan matrikulasi mampu meningkatakan kemampuan baca tulis al Quran mahasiswa Prodi PAI [3], kemampuan BTQ memberi pengaruh terhadap kemampuan mahasiswa UM Malang dalam membaca al Quran [5], [8], program matrikulasi BTQ dapat meningkatkan kemampuan baca tulis Al-Qur'an mahasiswa PAI [2], implementasi metode at Tartil mampu meningkatkan kemampuan baca dan tulis al Quran siswa MIN Persiapan [10], metode scaffolding mampu meningkatkan kemampuan baca dan tulis al Quran siswa kelas V MI Terpadu Ad Dimyati Bandung [6], keberhasilan pembelajaran BTQ tergantung pada faktor ketersediaan waktu, alat pendukung pembelajaran dan motvasi siswa SMK Muhammadiyah Jawa Timur [12], pembinaan BTQ mampu meningkatkan kemampuan membaca al Quran secara tartil pada siswa SMK Pariwisata Cirebon [8], dan keberhasilan pembelajaran BTQ dapat dicapai dengan menerapkan sistem kelompok dalam pembelajaran, melakukkan pembelajaran secara privat, hafalan, evaluasi pembelajaran secara bertahap dan rutin [9],[11].

\section{METODE PELAKSANAAN}

Pengabdian kepada masyarakat yang dilakukan oleh penulis menggunakan metode pendampingan. Metode ini dilakukan dengan melaksanakan pendampingan pembelajaran ekstrakurikuler BTQ pada siswa kelas V SDN 2 Kuwasen selama 36 kali tatap muka pada semester genap tahun pelajaran 2019/2020. Pendampingan pembelajaran BTQ dilaksanakan 3 (tiga) kali dalam seminggu pada hari Selasa, Jumat dan Sabtu mulai pukul 13.00 s/d 14.00 WIB. dengan menggunakan buku metode belajar baca tulis al Quran Yanbu'a. Tempat kegiatan pendampingan ini dilaksanakan di ruang kelas SDN 2 Kuwasen. Metode pembelajaran yang digunakan adalah ceramah, demonstrasi, simulasi dan praktek. Evaluasi hasil pembelajaran dilaksanakan dengan praktek membaca dan menulis al Quran secara mushafahah (authentic assessment).

Dampak dari hasil pengabdian ini disajikan dengan data yang dikumpulkan berupa data kuantitatif, yaitu score nilai hasil tes awal dan hasil tes akhir (pre dan post test). Data tersebut kemudian diolah untuk memperoleh rata-rata score nilai pra dan pasca pendampingan. Dari hasil analisis terhadap data tersebut kemudian digunakan untuk menarik kesimpulan mengenai dampak pendampingan pembelajaran BTQ terhadap kemampuan baca dan tulis al Quran siswa kelas V SDN 2 Kuwasen.

\section{Kerangka Kerja Pengabdian}

Untuk mempermudah dalam kegiatan pengabdian ini, maka penulis membuat kerangka kerja kegiatan seperti pada gambar 1 berikut ini 


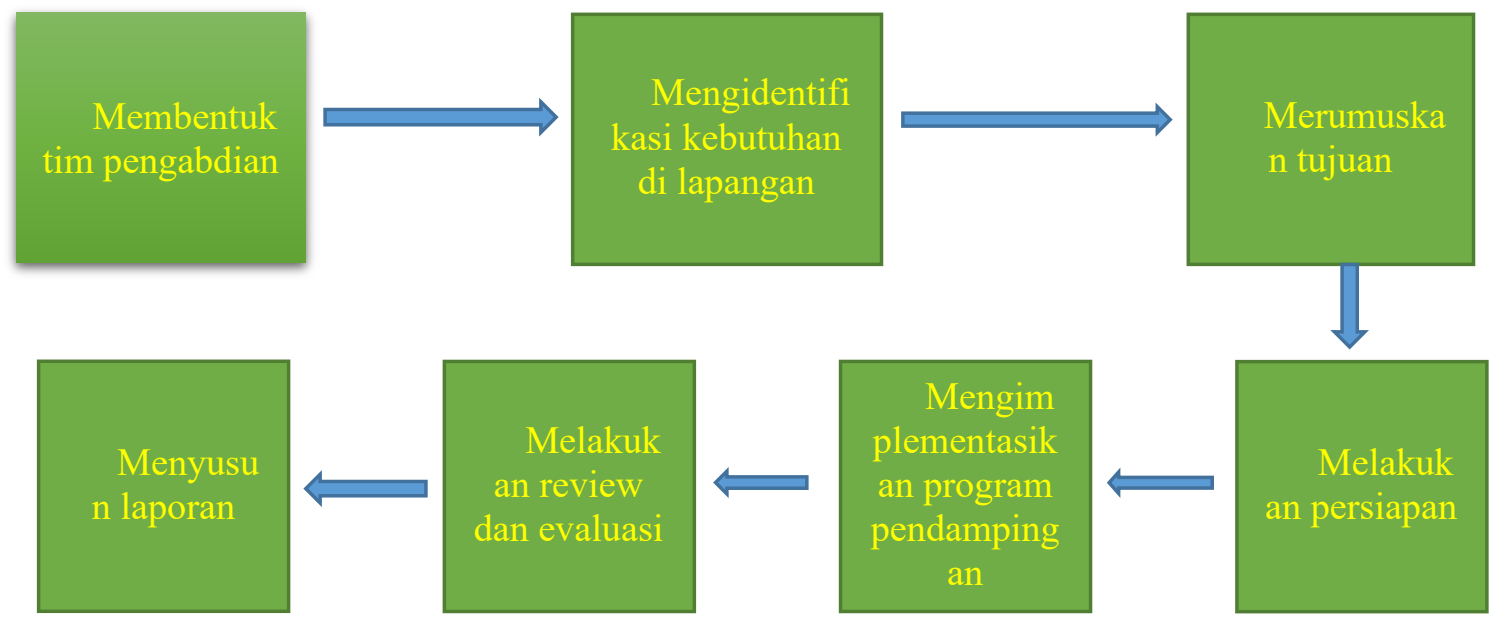

Gambar 1. Kerangka Kerja Kegiatan Pengabdian

Berdasarkan gambar 1, dapat diketahui tentang alur kegiatan pengabdian kepada masyarakat yang dilakukan oleh penulis. Pada tahap awal penulis membentuk tim yang terdiri 3 orang, 2 orang dosen dan 1 orang mahasiswa. Tim yang sudah terbentuk kemudian melakukan observasi, studi dokumen dan interview untuk memperoleh data tentang masalah dan kebutuhan riil di lapangan. Hasil dari identifikasi masalah kemudian dijadikan bahan untuk merumuskan tujuan dan sekaligus menentukan bentuk kegiatan pengabdian. Pada tahap persiapan sebelum pelaksanaan pengabdian, tim mempersiapkan segala kebutuhan yg menunjang kegiatan tersebut, meliputi; perangkat keras dan perangkat lunak. Selanjutnya tim melaksanakan pengabdian dengan mendampingi kegiatan pembelajaran BTQ di sekolah dengan cara tatap muka selama 5 bulan terhitung buan Pebruari sampai dengan Juni 2020. Setelah kegiatan pendampingan selesai tim melakukan evaluasi dalam bentuk post-test dan melakukan analisis hasil dan menyusun laporan kegiatan pengabdian.

\section{HASIL}

Menjelaskan proses pengolahan data, pelaksanaan, pembuatan dan apa saja yang berhubungan dengan hasil kegiatan pengabdian misalnya seperti dibawah ini:

\section{Dokumentasi Kegiatan}
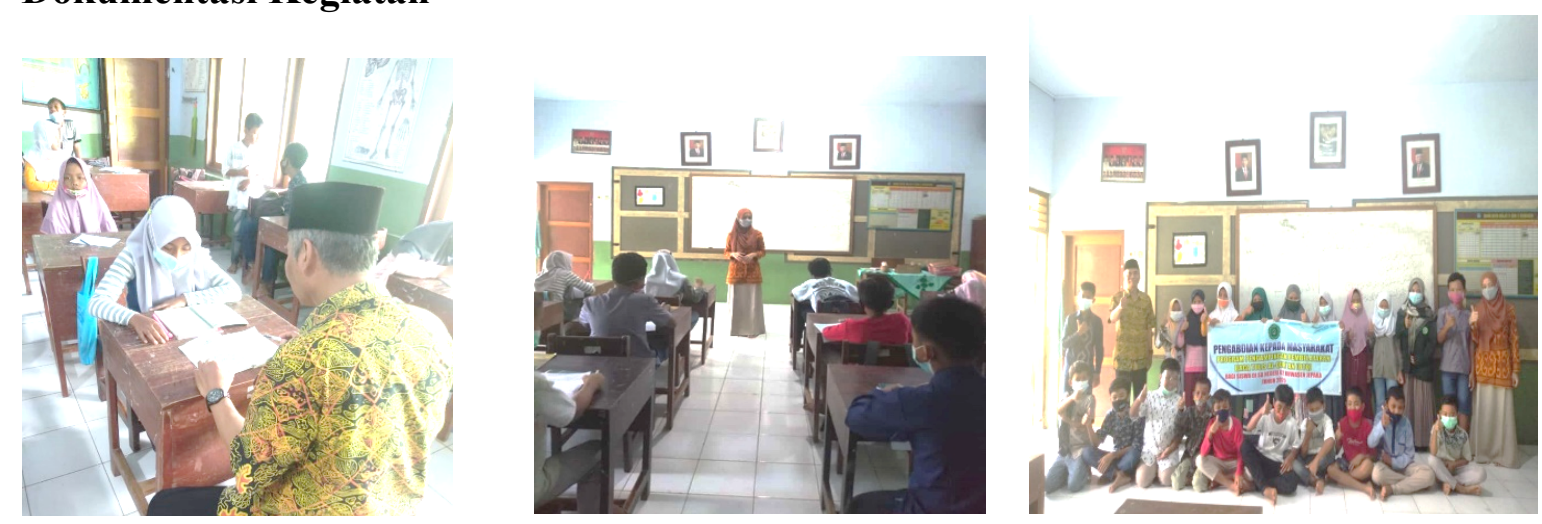

Gambar 2. Kegiatan penyampaian materi 
Kegiatan pendampingan pembelajaran baca dan tulis al Qur'an (BTQ) dilaksanakan dengan metode pembelajaran klasikal dan sorogan. Metode klasikal digunakan untuk memberikan penjelasan secara umum tentang materi baca dan tulis. Sedangkan metode sorogan digunakan untuk pendampingan secara individual saat praktek membaca dan menulis.

Materi pendampingan meliputi; 1) tajwid dan makhorijul huruf (membaca), dan 2) imla (menulis). Materi pelajaran diambilkan dari buku Yanbu'a. Materi tajwid disampaikan secara klasikal dengan penjelasan umum dan simulasi melafalkan al Quran yang benar, kemudian siswa diminta praktek satu persatu menirukan guru melafalkan kata dan kalimat dengan benar. Materi imla (menulis) disampaikan penjelasan umum secara klasikal tentang tata cara menulis huruf arab lepas dan kemudian bagaimana huruf-huruf tersebut dirangkai menjadi sebuah kata, dengan memberikan contoh di papan tulis. Setelah itu siswa diminta praktek menulis secara individu dengan didampingi guru. Siklus kegiatan pendampingan yang meliputi penjelasan teori dan simuasi dan dilanjutkan pratek ini dilaksanakan terus menerus selama pendampingan.

Untuk melaksanakan penilaian harian (formatif) guna memonitor penguasaan materi secara rutin, penulis menggunakan tehnik sorogan (privat, setoran satu persatu maju menghadap guru/penulis) untuk membaca dan menujukkan hasil tulisannya. Pada saat menghadap tersebut guru melakukan koreksi terhadap bacaan dan tulisan siswa secara individual. Di penghujung pendampingan, penulis melaksanakan post-test, dengan tehnik praktek membaca satu persatu di hadapan penulis. Sedangkan untuk menulis, siswa diminta praktek menulis huruf arab lepas, merangkai huruf menjadi kata dan menyalin ayat al Quran yang ditentukan oleh penulis.

Tabel 1.Tabel Pengolahan Data

\begin{tabular}{llllllll}
\hline \multirow{2}{*}{ No } & \multirow{2}{*}{ Nama } & Pre test & \multicolumn{3}{c}{ Post test } \\
\cline { 3 - 8 } & Baca & Tulis & $\begin{array}{l}\text { Rata- } \\
\text { rata }\end{array}$ & Baca & tulis & $\begin{array}{l}\text { Rata- } \\
\text { rata }\end{array}$ \\
\hline 1 & Bobby & 25 & 50 & 37,5 & 75 & 50 & 62,5 \\
\hline 2 & Sekar & 50 & 75 & 62,6 & 100 & 75 & 87,5 \\
\hline 3 & Faza & 100 & 100 & 100 & 100 & 100 & 100 \\
\hline 4 & Nasyilla & 75 & 50 & 62,5 & 87,5 & 75 & 81,2 \\
\hline 5 & Firqi & 75 & 50 & 62,5 & 50 & 75 & 62,5 \\
\hline 6 & Masya & 75 & 75 & 75 & 100 & 50 & 75 \\
\hline 7 & Sela & 75 & 50 & 62,5 & 75 & 50 & 62,5 \\
\hline 8 & Shafa & 87.5 & 75 & 81,2 & 100 & 87,5 & 93,7 \\
\hline 9 & Gabriel & 75 & 75 & 75 & 100 & 75 & 87,5 \\
\hline 10 & Hana & 100 & 87,5 & 93,7 & - & - & \\
\hline 11 & Vani & 50 & 75 & 62,5 & - & - & \\
\hline 12 & Havish Nauval & 50 & 75 & 62,5 & - & - & \\
\hline 13 & M Akbar Maulana & 62,5 & 50 & 56,2 & 100 & 75 & 87,5 \\
\hline 14 & Iqbal & 75 & 50 & 62,5 & 100 & 37,5 & 68,7 \\
\hline 15 & Andre & 25 & 50 & 37,5 & - & - & \\
\hline 16 & Revan Darmawan & 75 & 50 & 62,5 & 100 & 75 & 87,5 \\
\hline 17 & Falah & 50 & 50 & 50 & - & - & \\
\hline 18 & Reyhan & 87,5 & 87,5 & 87,5 & 87,5 & 75 & 81,2 \\
\hline 19 & Faarih & 100 & 75 & 87,5 & 100 & 62,5 & 81,2 \\
\hline 20 & Agung & 25 & 50 & 37,5 & 100 & 50 & 75 \\
\hline 21 & Ayu & 50 & 75 & 62,5 & 50 & 87,5 & 68,7 \\
\hline
\end{tabular}




\begin{tabular}{llllllll}
22 & Adeffa & 37,5 & 50 & 43,7 & 62,5 & 50 & 56,2 \\
\hline 23 & Niam & 75 & 100 & 87,5 & 100 & 87,5 & 93,7 \\
\hline 24 & Adit & 62,5 & 75 & 68,7 & 100 & 50 & 75 \\
\hline 25 & Dafa & 50 & 62.5 & 56,2 & - & - & \\
\hline 26 & Wildan & 75 & 50 & 62,5 & 100 & 50 & 75 \\
\hline & Rata-rata & 64,9 & 65,6 & 65,4 & 89,3 & 66,8 & 78,1 \\
\hline
\end{tabular}

Tabel 2. Interval nilai pre-test baca dan tulis

\begin{tabular}{cclcc}
\hline interval & Predikat & Keterangan & $\begin{array}{c}\text { Jumlah } \\
\text { siswa }\end{array}$ & $\%$ \\
\hline $86-100$ & A & Sangat baik & 5 & 19 \\
\hline $76-85$ & B & Baik & 1 & 4 \\
\hline $61-75$ & C & Cukup & 13 & 50 \\
\hline$\geq 60$ & D & Kurang & 7 & 27 \\
\hline Jumlah & & & 26 & 100 \\
\hline
\end{tabular}

Tabel 3. Interval nilai post-test baca dan tulis

\begin{tabular}{cclcc}
\hline interval & Predikat & Keterangan & $\begin{array}{c}\text { Jumlah } \\
\text { siswa }\end{array}$ & $\%$ \\
\hline $86-100$ & A & Sangat baik & 10 & 50 \\
\hline $76-85$ & B & Baik & 3 & 15 \\
\hline $61-75$ & C & Cukup & 6 & 30 \\
\hline$\geq 60$ & D & Kurang & 1 & 5 \\
\hline Jumlah & & & 20 & 100 \\
\hline
\end{tabular}

Berdasarkan tabel 2 dan 3 di atas diperoleh data bahwa siswa yang memperoleh nilai baik untuk baca dan tulis al Quran pada saat pre-test sebanyak 1 anak (4\%), sangat baik 5 anak (19\%). Sementara itu setelah dilakukan pendampingan pembelajaran BTQ, siswa yang memproleh nilai baik dalam post-test sebanyak 3 anak (15\%) dan yang memperoleh nilai sangat baik sebanyak 10 anak (50\%). Sedangkan siswa yang memperoleh nilai kurang pada saat pre-test sebanyak 7 anak (27\%), dan saat post-test hanya ada 1 anak (5\%) yang memperoleh nilai kurang. Data tersebut menunjukkan bahwa pendampingan pembelajaran yang dilakukan penulis memiliki dampak positif dalam meningkatnya kemampuan baca dan tulis al Quran siswa kelas V SD Negeri 2 Kuwasen. Hasil analisis data tersebut juga sekaligus memperkuat hasil penelitian yang dilakukan peneltiti terdahulu mengenai pengaruh pembinaan khusus pembelajaran di luar jam intra sebagaimana ditulis oleh [2], [12], [6], dan tentang metode dan strategi pembelajaran privat/sorogan dalam meningkatkan kemampuan BTQ siswa sebagaimana ditulis oleh [3], [9],[11], dan [10]. 

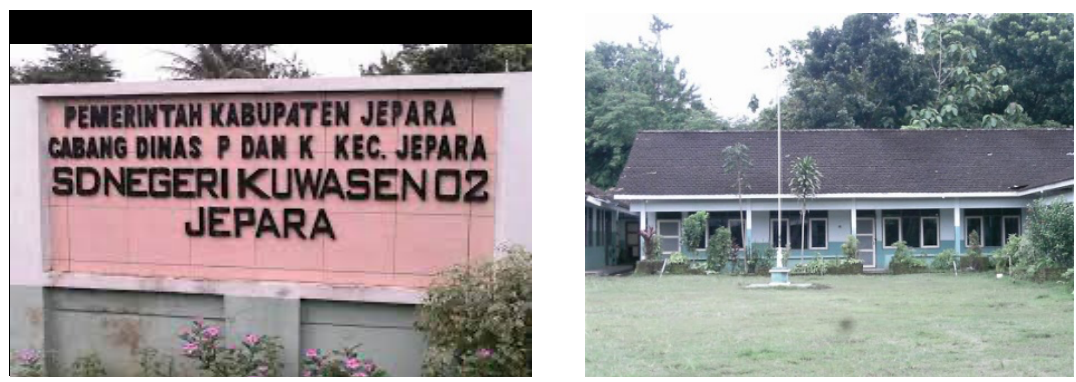

Gambar 3. Lokasi kegiatan

Lokasi tempat kegiatan pengabdian masyarakat berada di SD Negeri 2 Kuwasen. Sekolah ini berlokasi di desa Kuwasen RT 08 RW 02 kecamatan Jepara Kota, kabupaten Jepara. Lokasi SD Negeri 2 Kuwasen ini bearada di $\pm 6 \mathrm{~km}$ arah ke utara dari Kampus UNISNU Jepara, atau $\pm 1 \mathrm{~km}$ ke arah utara dari pusat kota Jepara.

\section{KESIMPULAN}

Berdasarkan hasil analisis data tentang rata-rata nilai pre-test dan post-test baca dan tulis al Quran siswa kelas V SD Negeri 2 diketahui bahwa ada peningkatan nilai rata-rata baca dan tulis al Quran setelah dilakukan pendampingan pembelajaran BTQ. Data tersebut menunjukan bahwa kegiatan pengabdian yang dilakukan dengan melakukan pendampingan pembelajaran baca dan tulis al Quran memiliki dampak dan manfaat dalam meningkatkan kemampuan baca dan tulis al Quran siswa kelas V SD Negeri 2 Kuwasen Kabupaten Jepara.

\section{DAFTAR PUSTAKA}

[1] Ani. Faktor yang mempengaruhi minat anak belajar baca tulis al-quran. Hasil wawancara dengan guru Kelas V SD Negeri 2 Kuwasen.

[2] Baihati, L., \& Diah Pramesti, S. L. "Peningkatan Kemampuan Baca Tulis Al-Qur'an Mahasiswa PAI Melalui Program Matrikulasi BTQ". TA'DIBUNA: Jurnal Pendidikan Agama Islam, 3(1), 2020. https://doi.org/10.30659/jpai.3.1.29-38

[3] Ismail, S. "Peningkatan Kemampuan Baca Tulis Al-Qur'an Melalui Metode Scaffolding Pada Siswa Kelas V MI Terpadu Ad-Dimyati Bandung". Atthulab, 3(2), 148-156. https://doi.org/10.15575/ath.v3i2.4210

[4] Jauhari, T. "Wawasan AI-Qur'an; Tafsir Maudu'i atas Berbagai Persoalan Umat". Mizan.

[5] Khadijah, S., \& Rejeki, S. P. F. "Efektivitas Komunikasi Tutor BTQ dan Kemampuan Membaca Al-Qur'an Mahasiswa". MAKNA: Jurnal Kajian Komunikasi Bahasa dan Budaya, 4(1) 2019. http://jurnal.unismabekasi.ac.id/index.php/maknassue/view/179. https://doi.org/10.33558/makna.v4i1.1123

[6] Maulida, P. R. "Pengaruh Pembinaan Baca Tulis Al Quran terhadap Kemampuan Membaca Al Qur'an Secara Tartil Siswa Kelas X SMK Pariwisata Kota Cirebon [IAIN Syekh Nurjati Cirebon]. https://core.ac.uk/download/pdf/147421641.pdf

[7] Ningrum, A. P., Dewi, N., Apriyanti, I., \& Rahmadhani, R. "Mengenal Pembelajaran Baca Tulis Alqur' an. Ihya Al-Arabiyah: Jurnal Pendidikan Bahasa dan Sastra Arab ", 51-56

[8] Puspitasari, K.. "Pengaruh Pembelajaran BTQ (BACA TULIS AL-QUR'AN) Terhadap Peningkatan Kemampuan Mahasiswa Dalam Membaca Al-Quran Di Universitas Muhammadiyah Malang" . http://eprints.umm.ac.id/40763/

[9] Putri, A. L. R. "Implementasi Kegiatan Ekstrakurikuler BTQ (Baca Tulis Al-Quran) Dalam 
Menanamkan Karakter Disiplin Dan Tanggung Jawab Peserta Didik Kelas IV Di SD Negeri Mangkubumen Kidul No.16 Surakarta [Universitas Muhammadiyah Surakarta]. http://eprints.ums.ac.id/77654/

[10] Wahyuni, A. N. "Implementasi Pembelajaran Baca Tulis al Quran dengan Metode at Tartil di MI Persiapan Negeri Miftahul Huda Turen". UIN Maulana Malik Ibrahim Malang".

[11] Wardoyo, E. H. "Penerapan Metode Pembelajaran Baca Tulis Al Qur'an Pada Siswa di SDN Sebani Kecamatan Sumobito Kabupaten Jombang. Sumbula Jurnal Studi Keagamaan, Sosial Dan Budaya, Volume 1(2) 2020.

[12] Wibawa, R. A. "Pendidikan Baca Tulis Al-Quran (BTQ) di SMK Muhammadiyah Jawa Timur (Studi Kasus Pembelajaran BTQ di SMK Muhammadiyah 1 Taman Sidoarjo) Halaqa: Islamic Education Journal Volume 2(2), 182-189. 2018. https://doi.org/10.21070/halaqa. 